\title{
Sustainable Development-utopia or our chance? Some thoughts on the state of the SDG implementation with respect to the ocean
}

\author{
Zrównoważony rozwój - utopia czy nasza szansa? \\ Kilka przemyśleń na temat stanu wdrożenia SDG w odniesieniu \\ do oceanu \\ Tymon ZIELIŃSKI ${ }^{1}$ \\ Institute of Oceanology Polish Academy of Sciences \\ Izabela KOTYŃSKA-ZIELIŃSKA² \\ Today We Have \\ Ewa PIECHOWSKA ${ }^{3}$ \\ Institute of Oceanology Polish Academy of Sciences
}

\begin{abstract}
In this work we discuss the importance of the application of sustainable development goals (SDGs) to all aspects which are related to the ocean. We argue that the ocean is interconnected and processes which are related to the ocean have direct impact on all SDGs, and any action undertaken within any of the SDGs will have an impact on the ocean. We believe that widely understood education of societies can ensure the proper understanding and hence implementation of the sustainable development idea throughout the world.
\end{abstract}

1 https://orcid.org/0000-0003-4712-8899.
2 https://orcid.org/0000-0002-7099-8692.
3 https://orcid.org/0000-0002-0120-3403. 
Keywords: Sustainable development, Sustainable Development Goals, Ocean, Climate change, Education

Streszczenie

W niniejszej pracy przedstawiamy jak ważnym jest proces wdrażania celów zrównoważonego rozwoju w kontekście problemów związanych z oceanem. Pokazujemy, że ocean jest jedną wielką, wzajemnie współzależną całością i dlatego wszelkie procesy, zachodzące w szerokim znaczeniu oceanu, mają wpływ na każdy z celów, a z kolei jakiekolwiek działanie w obrębie któregokolwiek celu ma wpływ na ocean. Twierdzimy, że szeroko rozumiane działania edukacyjne, dedykowane wszelkim grupom wiekowym i społecznym, jak również podejście interdyscyplinarne są podstawą do sukcesu we wdrażaniu idei zrównoważonego rozwoju w skali od lokalnej do globalnej.

Słowa kluczowe: zrównoważony rozwój, cele zrównoważonego rozwoju, ocean, zmiana klimatu, edukacja

\section{Introduction}

Ocean, which covers c. 70\% of Earth surface, is a vital piece in a puzzle called planet Earth and thus has a decisive impact on humankind (UNESCO, 2017; UN, 2016). All things, which on a daily basis, are crucial to people are concerned with the ocean, from climate system, through air we breathe, drinking water availability, food source to entertainment. Ocean affects human lives regardless of how far from the coast they live (Costanza, 1999; Beaumont et al., 2007).

Our use of the ocean, through growing populations and developing economies, including industrial, agricultural, recreational activities, has significant impact on the health of the ocean as a whole, however, it is especially true in the coastal regions (UNESCO, 2017).

Climate change, with its global warming and acidification of ocean waters causes serious and yet not fully understood effects on ocean ecosystems, which, in turn, have serious implications for food security and many ocean related industries. For many species, the fast changes in their habitats cause the change in entire ecosystems and the range of the changes is still unknown, as well as the interactions between changes in the ocean and responses to the different scales of the changes. Currently, we are still lacking effective tools for mitigation and adaptation to the changing system (Cheung, et al., 2013; Costanza 1997).

However, starting in 2004, actions have become more coordinated due to the acceptance of the regular process to report on the environmental, economic 
and social aspects of the world's ocean on the level of the United Nations (UN) General Assembly (UNEP and IOC-UNESCO, 2009). The Regular Process for Global Reporting and Assessment of the State of the Marine Environment, including Socioeconomic Aspects published the first global integrated assessment of the marine environment in December 2016 (commonly referred to as the first World Ocean Assessment). Following the first Assessment, the second Assessment, is to be delivered in 2020, and it is created using the baselines included in the first Assessment, but it is focused on establishing trends in the marine environment with relevance to global reporting needs such as those associated with the UN Sustainable Development Goals (Ruwa et al., 2017). The second Assessment process focuses on the use of current ocean observation and monitoring information to provide a complex view of all aspects, including physical, chemical, biological, social, economic and cultural components of widely understood ocean environments and to evaluate their state (Ruwa et al., 2017, Evans et al. 2018).

Equally important is to provide information that can be applied to address management and policy requirements at all scales from local, through regional to global (Ruwa et al., 2017). What is vital for the better understanding of the changes, which occur in the ocean, is to properly identify both knowledge gaps and capacity needs in order to well develop sustained observation systems that are required for enhancing proper ocean related knowledge (Bax et al, 2018; Miloslavich et al., 2018). To enhance our knowledge of the state of the ocean and provide effective management tools to achieve its sustainable use, we need enhanced support for scientific research and better means for technology transfer. One way of achieving it is to follow the philosophy, which has been set behind the Sustainable Development Goals (Ruwa et al., 2017, Evans et al. 2019). All 17 goals are fully interrelated, and thus meeting the target of one of them ensures that all other targets associated with other goals are also met. The acceptance of this philosophy needs to be achieved on every societal level, from regular citizens to decision makers. In order to achieve such agreement, means for proper education and communication about the importance of the sustainable development for all of us must be developed. Therefore, especially important are all these goals, which are directly referring to a widely understood education.

Our planet is in the phase of global change, which includes severe changes in many ecosystems, and thus it is critical to efficiently communicate research plans and obtained results to all citizens. In the process of increasing the awareness of the changes, education, at all levels, plays a crucial role 
However, we realize that today's interest in science among societies is declining and it is concerned with the fact that usually science is presented without context and thus it seems irrelevant to people, which results in confusion between science and pseudoscience (Kotynska-Zielinska and Papatahnasiou, 2018). This is a dangerous situation since due to democratic procedures people are involved in an increased public participation in decisionmaking, and thus distorted perception of the reality leads to wrong decision making (Bray, France and Gilbert, 2012).

It is, therefore, crucial to highlight the importance of science and its relevance to peoples' lives (Lubchenco and Grorurd-Colvert, 2015; Stocklmayer and Bryant, 2012). Citizens need scientifically based information, which is more positive and embedded in realistic demonstrations of the current limitations of science, to create trust in what scientists communicate to societies (Anderhag, Emanuelsson, Wickman and Hamza, 2013).

Therefore, in order to promote sustainable development, researchers and educators together need to use an integrated and cross-sectoral approach to promote the ocean issues, its problems, ways to mitigate the changes and tools how to adapt to these changes.

\section{Discussion}

\subsection{Issues to be considered with respect to SDG implementation to the ocean}

Since vast ocean areas are actually beyond any real jurisdiction there are serious gaps in knowledge and lack of experts, who could lead activities aiming at proper ocean management. All the human based pressures and various types of pollution have great impact on marine biodiversity, which in turn influences food security for humans (Ruwa et al., 2017). For many years, human activities have caused noticeable environmental damage, and we are still at a stage of trying to identify its nature and scale. The development and further implementation of the tools and means for mitigation and hence limitation of human impacts are necessary actions, which humans must undertake in order to control these problems (Ruwa et al., 2017, Evans et al. 2019).

However, continued increase in global production, results in increased emissions and discharges of various substances (including, those which are hazardous) into the ocean. Without new, innovative (i.e. clean) industrial technologies the improvement in ocean condition with respect to 
anthropogenic emissions and discharges is endangered (Newton et al., 2015; POGO, 2018).

The greater human activity and its role in polluting the ocean also includes agricultural activities, which have been rapidly increasing in the last century causing an enhanced run-off of both agricultural nutrients and pesticides. Increasing and unfortunately often uncontrolled loads of nutrients from various sources, including agriculture and sewage systems enable harmful algal blooms to occur more frequently and at larger scales. Such events influence aquacultures and affect recreation activities at beaches as well as create anoxic and hypoxic zones, conditions, which are adverse for most marine species. Therefore, in coastal areas, issues concerning improved sewage treatment are of the key importance for the environment to achieve healthy marine ecosystem and hence beneficial conditions for local and global societies at various levels of the environmental use.

Additional level of environmental problems for the ocean is concerned with shipping emissions and discharges of oil, however, over the past several decades, significant progress has been made in reducing oil discharges and in avoiding sea catastrophes. Nevertheless, there are still vulnerable areas, those where ship traffic is exceptionally heavy, such as, e.g. the English Channel or the Danish Straits.

Coastal regions are especially endangered due to rapid development, significant industrial production and shipping (Ruwa et al., 2017). Coastal regions are regarded as best areas for industrial and recreational development due to their proximity to ports. A great number of people live in the coastal zone. Around $38 \%$ of the world's population lives within a distance of 100 kilometres from the beach, and in many areas these numbers are constantly increasing. In order to meet the needs for space, activities concerned with land reclamation are taking place, and they usually have adverse impact on ocean environment (e.g. salt marshes and mangroves). Large natural river systems are changed through the construction of various installations, including dams and ports, which result in many both local and regional environmental changes.

Fast development of aquacultures needs space, most often located within the coastal areas, while the success of aquaculture production is guaranteed by the access to clean waters. Another issue of coastal development concerns the location of wind, wave and tidal installations, which at all stages of the production from their setting, through maintenance, affect the marine 
ecosystem, including such aspects as species migration routes their feeding and breeding patterns (Ruwa et al., 2017).

Lack of integrated and complex management of the human based pressures, and the climate change, coastal ecosystem benefits for humans and their resilience will be reduced or even disappear (UN, 2016; Ruwa et al., 2017).

\subsection{Specific interconnections among selected SDGs and the ocean}

Achieving a sustainable ocean, which is the target in the Sustainable Development Goal 14, will result in achieving other Goals. Goals 1, 2, 8, will be realized through e.g. securing proper management of fish stocks and protecting fish and seaweed quality to safeguard the vital role of food from the sea in securing food for the world's population (Ruwa et al., 2017). This is also done through the support of small-scale fisheries, which provide food and hence income, similarly to sustainability achieved in such sectors as tourism, shipping and sea-oriented industries (Ruwa et al., 2017, Evans et al. 2019).

The need for healthy food from the ocean is included in Goal 3, through ensuring of healthy lives and promotion of well-being for all people. The hazard for the safety of ocean food comes from contamination from pathogens and toxins, including poisonous algal blooms.

Goal 6: Ensure availability and sustainable management of water and sanitation for all, involves such vital issues as e.g. desalinization, which makes a major contribution to the freshwater supply in some parts of the world. In some Arabic countries up to $90 \%$ of freshwater supply comes from this source. The ocean is the key element in all climate processes and has the great potential to mitigate the change (Goal 13). Achieving sustainable ocean ecosystem and thus a healthy ocean will result in climate mitigation.

Climate change reduces rainfall in many parts of the globe, some of them are highly populated, and thus desalinization is becoming a significant tool for the change mitigation.

Developments, which have been made globally within the framework of Goal 7: Ensure access to affordable, reliable, sustainable and modern energy for all, have led to the fact that energy from wind, wave and tidal power is already a significant source of energy in many countries.

Goal 8 is interrelated with many other goals, since it promotes sustained, inclusive and sustainable economic growth, full and productive employment and decent work for all (Ruwa et al., 2017). This is directly related to such 
maritime industries as port and shipyard activities, maritime transport and submarine cable communications.

Many global trends related to the ocean environment already show a shift towards greater equality and sustainable use of fish stocks (Goals 10 and 12) (Ruwa et al., 2017).

On the other hand, the achievement of a number of Sustainable Development Goals will help in delivering Goal 14. Some examples involve, the improvement of the situation of women working in small-scale fisheries will result in facilitating of a bigger contribution to the well-being of local communities (Goal 5). Improvements in sanitation and management of waste results in the improvement of the quality of the ocean environment and, hence in better quality of food from the sea and reduced pressures on the marine environment, which are associated with various types of pollution (Goal 6) (Miloslavich et al., 2018).

Responsible, thus sustainable spatial planning, with regard to coastal areas, especially various coastal and offshore installations, but also cities results in inclusive and sustainable areas for people to live (Goal 11), while ensuring sustainable consumption and production patterns (Goal 12) requires work towards sustainable patterns of consumption and production (Ruwa et al., 2017).

Goal 13: Take urgent action to combat climate change and its impacts, involves actions to reduce and/or mitigate those impacts, and thus to mitigate adverse, climate change related impacts, which affect the health and productivity of the ocean.

None, of the above actions can be successful unless the Goal 17: Strengthen the means of implementation and revitalize the Global Partnership for Sustainable Development is properly delivered.

\section{Conclusions}

The ocean environment is at a vulnerable state and the greatest threat is concerned with inadequate and slow response to many of its problems. This threat is both of natural and anthropogenic origins (Markowicz et al., 2012). If these problems are not quickly addressed, there is a serious risk that the ocean can no longer provide many of the benefits that humans currently enjoy.

In our opinion, education of societies at all levels and ages is crucial to securing the sustainable development with respect to the ocean (National 
Geographic Society et al., 2005). Only properly educated society may be able to understand the significance of sustainable development for their lives at all levels from local to global.

Scientifically based knowledge is crucial in producing creative and active societies, who can further collaboratively face the complex challenges of the today's world. Such societies better function in the today's reality and hence can better plan their future. Some of the important issues, which make science education crucial for any society include promotion of culture for critical, science based, thinking to inspire citizens to use facts as the basis for decision making, through the provision of knowledge and skills and thus confidence, to take actions in the today's world (Kotynska-Zielinska and Papatahnasiou, 2018).

\section{References}

UNESCO (2017). Global Ocean Science Report - The current Status of Ocean Science Around the world. Paris: UNESCO Publishing.

UN (United Nations) (2016). The First Global Integrated Marine Assessment. World Ocean Assessment I. Cambridge: Cambridge University Press.

Costanza R. (1999). The ecological, economic and social importance of the oceans. Ecol. Econ., 31 (2), 199-213.

Beaumont N. J., Austen M.C., Atkins J.P., Burdon D., Degraer S., Dentinho T.P., Derous S., Holm P., Horton T., van Ierland E., Marboe A.H., Starkey D. J., Townsend M., Zarzycki T. (2007). Identification, definition and quantification of goods and services provided by marine biodiversity: implications for the ecosystem approach. Mar. Pollut. Bull., 54 (3), 253-265.

Cheung W. W. L., Watson R., and Pauly D. (2013). Signature of ocean warming in global fisheries catch. Nature 497, 365-368. doi: 10.1038/nature 12156.

Costanza R., d'Arge R., de Groot R., Farber S., Grasso M., Hannon B., et al. (1997). The value of the world's ecosystem services and natural capital. Nature 387, 253260. doi: $10.1126 /$ sciadv. 1601880 .

UNEP and IOC-UNESCO (2009). An Assessment of Assessments, Findings of the Group of Experts. Start-up phase of a Regular Process for Global Reporting and Assessment of the State of the Marine Environment including Socioeconomic Aspects. Nairobi: UNEP.

Ruwa R., A. Simcock, M. J. Bebianno, H. P. Calumpong, S. Chiba, K. Evans, O. K. Kamara, E. Marschoff, M. McClure, E. Y. Mohammed, Ch. Park, L. Y. Randrianarisoa, M. E. Sanchez, A. Strati, J. Tuhumwire, T. Ca Vu, J. Wang, Zielinski T. (2017). The Ocean and the Sustainable Development Goals under the 2030 Agenda for Sustainable Development; A Technical Abstract of the First 
Global Integrated Marine Assessment, United Nations; eISBN 978-92-1-3613719; 48 pp.

Evans K., Bax N. and Smith D. C. (2018). Enhancing the robustness of a national assessment of the marine environment. Mar. Pol. 98, 133-145. doi: 10.1016/j.marpol.2018.08.011.

Bax N. J., Appeltans W., Brainard R., Duffy J. E., Dunstan P., Hanich Q., et al. (2018). Linking capacity development to GOOS monitoring networks to achieve sustained ocean observing. Front. Mar. Sci. 5: 346. doi: 10.3389/fmars.2018.00346.

Miloslavich P., Bax N. J., Simmons S. E., Klein E., Appeltans W., Aburto-Oropeza O., et al. (2018). Essential ocean variables for global sustained observations of biodiversity and ecosystem changes. Glob. Change Biol. 2018, 2416-2433. doi: 10.1111/gcb.14108.

Evans K., Chiba S., Bebianno M.J., Garcia-Soto C., Ojaveer H., Park C., Ruwa R., Simcock A.J., Vu C.T., Zielinski T. (2019). The global integrated world ocean assessment: Linking observations to science and policy across multiple scales. Frontiers in Marine Science, doi: 10.3389/fmars.2019.00298.

Kotynska-Zielinska I., Papatahnasiou M. (2018). Examples of innovative approaches to educate about environmental issues within and outside of classroom, in: Interdisciplinary Approaches for Sustainable Development Goals. GeoPlanet: Earth and Planetary Sciences, doi.org/10.1007/978-3-319-71788-3_3.

Bray B., France B. and Gilbert J. K. (2012). Identifying the essential elements of effective science communication: what do the experts say? Int. J. Sci. Educ. B 2, 23-41. doi: 10.1080/21548455.2011.611627.

Lubchenco J. and Grorurd-Colvert K. (2015). Making waves: The science and politics of ocean protection. Science, 350, 382-383.

Stocklmayer S. M and Bryant C. (2012). Science and the Public-What should people know? International Journal of Science Education, Part B: Communication and Public Engagement, 2(1), 81-101, doi:10.1080/09500693.2010.543186.

Anderhag P., Emanuelsson P., Wickman P. O. and Hamza K. M. (2013). Students' Choice of Post-Compulsory Science: In search of schools that compensate for the socio-economic background of their students. International Journal of Science Education, 35(18), 3141-3160.

Newton J. A., Feely R. A., Jewett E. B., Williamson P. and Mathis J. (2015). Global Ocean Acidification Observing Network: Requirements and Governance Plan. Available at: www.goa-on.org/docs/GOA-ON_plan_print.pdf (accessed June 27, 2016).

POGO (2018). The value of the Global Ocean Observing System and the Regular Assessment of the State of the Ocean in Support of Wise Decision-Making. A Statement by the Partnership for Observation of the Global Ocean (POGO). Plymouth: Partnership for Observation of the Global Ocean. 
Markowicz K., Zielinski T., Pietruczuk A., Posyniak M., Zawadzka O., Makuch P., Stachlewska I., Jagodnicka K., Petelski T., Kumala W., Sobolewski P., Stacewicz T. (2012). Remote sensing measurements of the volcanic ash plume over Poland in April 2010, Atmospheric Environment, Volume: 48 Special Issue: SI, 66-75.

National Geographic Society [NGS], National Oceanic, Atmospheric Administration, Centers for Ocean Sciences Education Excellence, National Marine Educators Association, and College of Exploration. (2005). Ocean Literacy: The Essential Principles of Ocean Sciences $K-12$. Silver Spring, MD: NOAA. 